\title{
МОДЕЛЬ СТРУКТУРНОЙ И ФУНКЦИОНАЛЬНОЙ ОРГАНИЗАЦИИ ПСИХОСЕМАНТИЧЕСКОЙ СИСТЕМЫ СЕМЕЙНОЙ ЦЕЛЕНАПРАВЛЕННОСТИ
}

\author{
Наталья Валентиновна Нозикова \\ кандидат психологических наук, дочент \\ Тихоокеанский государственный университет \\ 2. Хабаровск, Россия \\ E-mail:nv_nozikova@bk.ru
}

На основе эмпирического исследования представлена модель структурной и функциональной организации семейной психосемантической целостности. Гипотеза работы предполагает, что теоретическая модель анализа психосемантической целостности позволит выявить принципы структурной и функциональной организации психосемантической системы семейной целенаправленности.

Выборку составили: девушки и юноши 15-18 лет, учащиеся средних школ; женщины и мужчины 20-44 лет, состоящие в браке и воспитывающие детей. Применялась компьютерная программа Osgood модифицированного варианта методики семантического дифференциала И. Л. Соломина.

Выполнена модификация принципа формирования списка понятий для оценки испытуемыми методики семантического дифференциала. $\mathrm{B}$ соответствии с иелью исследования подобраны: 1) категории понятий, относящихся к семейной жизни (люди и группы, события, виды деятельности и идеальные представления); 2) понятия-маркеры, определяющие базовые ценности, этапы жизненного пути, людей, группы людей и отношения к ним, гендерные понятия, занятия и виды деятельности, эмоциональные переживания и события.

Общие принципы психосемантического анализа и полученные нами результаты исследования психосемантической челостности позволили предложить теоретическую модель структурного и функционального анализа психосемантической системы. На ее основе выполнен сравнительный анализ психосемантической системы в зависимости от факторов пола, возраста и семейного состояния респондентов. Это позволило сформулировать следующие принципы организации модели психосемантической системы семейной целенаправленности: 1) принцип семантического критерия организации целостности; 2) принцип структурной организации, предполагающий анализ 
структурных и качественных характеристик целостности, субсистемных кластеров понятий, выполняющих специфические функциональные задачи, и компонентов-понятий рассматриваемой сфреры жизни; 3) приниип функциональной целенаправленности, обусловленный доминирующими ченностями в зависимости от факторов пола, возраста и семейного состояния; 4) принцип функциональной организации психосемантической целостности. Полученные данные будут востребованы в практике семейной психологии.

Ключевые слова: социальная психология, психосемантическая система, структурная организация, функциональный анализ, модель, семья, развод, семейная целенаправленность, семейная идентичность.

Для цитирования: Нозикова Н. В. Модель структурной и функциональной организации психосемантической системы семейной целенаправленности // Российский психологический журнал. - 2016. - Т. 13. - № 3. - С. 221-244.

\title{
THE MODEL OF STRUCTURAL AND FUNCTIONAL ORGANIZATION OF THE PSYCHO-SEMANTIC SYSTEM OF FAMILY PURPOSEFULNESS
}

\author{
Natalia Valentinovna Nozikova \\ Candidate of Psychology, Associate Professor \\ Pacific National University \\ Khabarovsk, Russia \\ E-mail:nv_nozikova@bk.ru
}

The paper presents the empirical model of structural and functional organization of family psycho-semantic integrity. The hypothesis is that the theoretical model of the analysis of psycho-semantic integrity makes it possible to reveal principles of structural and functional organization of the psycho-semantic system of family purposefulness.

The sample included (a) 15-18year-old young men and women (secondary school students) and (b) 20-44 year-old men and women (married and raising children). I. L. Solomin's Osgood program of the semantic differential method modified variant was used.

In order to assess the technique of semantic differential by respondents, a modification of the principle of formation of the list of concepts was carried out. In accordance with the research objective the authors chose: (a) categories of concepts related to family life (people and groups, events, activities, and ideal representation); (b) concepts-markers defining basic values, life stages, people, groups of people, relations to them, gender concepts, activities and types of activity, and emotional experiences and events. 
General principles of psycho-semantic analysis and the results of the study of psycho-semantic integrity enabled authors to propose a theoretical model of structural and functional analysis of the psycho-semantic system. This model formed the basis for the comparative analysis of the psycho-semantic system depending on factors of gender, age, and marital status of the respondents. The carried out study made it possible to distinguish the following principles of the psycho-semantic model of the system of family purposefulness: 1) principle of the semantic criterion of the organization of integrity; 2) principle of structural organization, involving the analysis of structural and qualitative characteristics of integrity, subsystem clusters of concepts performing specific functional tasks, and components - concepts of the considered area of life; 3) principle of functional purposefulness determined by dominating values, which depend on factors of gender, age, and marital status; 4) principle of the functional organization of psycho-semantic integrity. The findings are of direct practical relevance in the practice of family psychology.

Keywords: social psychology, psycho-semantic system, structural organization, functional analysis, model, family, divorce, family purposefulness, family identity.

For citation: Nozikova N. V. The Model of Structural and Functional Organization of the Psycho-Semantic System of Family Purposefulness. Russian Psychological Journal, 2016, V. 13, no. 3, pp. 221-244.

Широта междисциплинарных исследований семьи обусловлена ее фундаментальной ролью в реализации общественной жизни человека. Это определяет необходимость разработки приемов и методов изучения психосемантической системы, определяющей семейное поведение, и их использования для повышения эффективности комплексных социальноэкономических и демографических программ социальной практики.

Цель статьи - предложить структурно-функциональную модель психосемантической системы семейной целенаправленности.

\section{Теоретические основы моделирования функциональной психосе- мантической системы семейной целенаправленности}

Социально-демографические проблемы современного общества определяют необходимость изучения на основе системного подхода психосемантической организации ценностно-смысловых комплексов в сознании человека, определяющих реализацию семейного поведения.

Методология системного подхода определяет последовательность исследовательских действий, общая гносеологическая цель которых состоит в теоретическом обобщении ключевых признаков системной организации 
объекта, в том числе онтологических, структурных, функциональных, генетических и интегративных $[3,4]$.

Экспериментальные методы психосемантики позволяют исследовать «формы существования значения в человеческом сознании (выделено нами. H. Н.), ... содержание сознания субъекта, его картину мира, включающую как осознаваемые, так и неосознаваемые пласты ментальности» [14, с. 58].

Одной из задач психосемантического исследования является обобщение результатов в модели, воспроизводящей основные характеристики изучаемой области. Прием моделирования при изучении некоторого естественного объекта, в том числе в психологических исследованиях, позволяет на основе формализации результатов получить обобщенные теоретические знания о непротиворечивой, семантически адекватной, завершенной в полноте своих компонентов системе. Если модель исследуемого объекта представляет наиболее важные, значимые и ценные характеристики своего прототипа, то ее можно признать нормативной и целенаправленной $[2,15]$.

Общая задача структурного исследования объекта сводится к выявлению целостности из среды на основе критерия-дискриминатора, определения его цели, компонентного состава и структурно-иерархических связей [3].

Общенаучная теория систем определяет континуум пяти иерархически организованных структурных уровней системы на основе критерия дискриминатора, особенности которого основаны на специфике предмета исследования. Первый иерархический уровень-уровень целостности процесса или явления в его структурных и качественных характеристиках-представлен общесистемным уровнем. Второй уровень по своему содержанию гетерогенен и представлен отдельными подсистемами целостности с различными функциональными задачами - это субсистемный уровень. Третий уровень содержит базовые структурные компоненты. Четвертый структурный уровень представлен элементами, которые являются онтологически необходимыми для базовых компонентов системы, но утратившими качественную определенность целого. Система входит в состав и взаимодействует с внешней по отношению к ней метасистемой, которую в структурном анализе рассматривают как пятый уровень [3].

Следующий этап изучения функциональной организации системы в биологических и социальных науках предполагает анализ динамичных функциональных образований и прочессов, способных при широком диапазоне внешних изменений сохранять целостность, устойчивость и жизнеспособность системы [1].

Процессуальное качество организации психических процессов, по мнению А. В. Карпова, состоит, во-первых, в феномене функциональной системности объекта, который проявляется «...качествами, особенностями, 
характеризующими его как целостность, придающими ему организованность и выступающих в качестве его общих регуляторов. ... Эти качества... обнаруживаются экспериментально в факте существования значимых эффектов взаимодействия всех этапов реализации» [3, с. 243]. Во-вторых, хронологическим типом организации процесса функционирования, который «...является источником новой категории системных качестввременных, обнаруживаемых в плане целостной временной динамики процесса» [3, с. 243].

Итак, разработка модели структурной и функциональной организации психосемантической системы определяет необходимость сформировать обобщенные теоретические знания о наиболее существенных характеристиках целостного объекта, в число которых будут входить:

- структурные и функциональные единицы, выделенные в соответствии с семантическим критерием и определяющие реализацию основных функциональных задач целостности;

- цель, целенаправленность функционального процесса, образованная на основе доминирующих идеальных целей, мотивов и ценностных ориентаций человека или группы, которая формирует и сохраняет специфическую функциональную организацию системы на всем протяжении ее существования;

- принципы функциональной системности объекта, проявляющиеся во взаимодействии и преемственности этапов ее воплощения в хронологическом порядке;

- временные динамические качества организации процесса.

Гипотеза настоящего исследования предполагает, что теоретическая модель структурной и функциональной организации психосемантической целостности позволит выполнить анализ объекта в зависимости от факторов пола, возраста и семейного состояния и выявить основные принципы организации психосемантической системы семейной целенаправленности.

Для верификации выдвинутой гипотезы целесообразно выполнить следующие эмпирические задачи:

1) на основе общих психосемантических принципов анализа и выводов исследований, выполненных нами, разработать теоретическую модель структурного и функционального анализа психосемантической системы;

2) рассмотреть структурные характеристики психосемантической системы семейной целенаправленности в зависимости от факторов пола, возраста и семейного состояния;

3) выполнить анализ динамичных процессуальных хронологически организованных функциональных характеристик психосемантической системы семейной целенаправленности в зависимости от пола, возраста и семейного состояния респондентов; 
4) обобщить результаты структурного и функционального анализа и сформулировать принципы организации структурной и функциональной модели психосемантической системы семейной целенаправленности.

\section{Организация и методы исследования}

Исследование проводилось с января по май 2014 г. в очной групповой форме. Выборку составили всего 195 участников, в том числе:

- на базе образовательных учреждений МБОУ СОШ № 30, № 32, № 80, гимназии № 3 им. М. Ф. Панькова, лицея «Ступени», г. Хабаровск. В нем участвовали учащиеся 10-11 классов в возрасте от 15 до 18 лет, в том числе 50 девушек (средний возраст 16,5 лет) и 50 юношей (средний возраст 16,4 лет);

- на базе заочного отделения факультета дошкольного, начального и специального образования и факультета дополнительного образования Дальневосточного государственного гуманитарного университета, г. Хабаровск. Участниками исследования стали 50 женщин 21-44 лет (средний возраст 32,5 лет) и 45 мужчин в возрасте от 20 до 42 лет (средний возраст 31,5 лет), состоящие в браке и воспитывающие детей.

Социально-демографический анализ групп показал, что участники имели опыт семейной, супружеской жизни и воспитания детей.

Исследование семейной целенаправленности выполнено с помощью компьютерной программы Osgood модифицированного варианта методики семантического дифференциала (СД) в пакете методик психосемантической диагностики мотивации (ПДМ), разработанного И. Л. Соломиным [16, 18, 19, 20].

На основе 18-ти шкал, наиболее значимо определяющих факторы ценности, потенции и активности, испытуемые оценивали подобранные нами в соответствии с целями работы 38 понятий, представляющих различные категории, характеризующие потребности и ценности личности, людей и их группы, гендерные представления, этапы жизненного пути, эмоциональные переживания и события.

Методы анализа данных основаны на применении программы Osgood, которая позволяет выполнить расчет среднего арифметического значения и стандартного отклонения по факторам ценности, потенции и активности для каждого из предложенных испытуемому понятий. Показатели стандартного отклонения выявляют устойчивость оценок понятия по фактору ценности респондентом и косвенно свидетельствуют о степени их надежности. Стандартное отклонение выше 2,0 указывает на затруднения респондентов в оценке и сниженную надежность полученных результатов, а стандартное отклонение, равное нулю, говорит о ригидности испытуемого в оценочной деятельности или о нежелании быть откровенным [16]. 
В настоящем исследовании показатели стандартного отклонения результатов оценки по фактору ценности понятий для групп девушек, юношей, женщин и мужчин, представленные в таблице 1, не превысили 1,15 единиц, что подтвердило их надежность. Достоверность полученных результатов обеспечивалась репрезентативностью и объемом выборки.

Таблица 1.

\section{Оценка понятий семейной целенаправленности по фактору ценности} в зависимости от пола и возраста респондентов

\begin{tabular}{|c|c|c|c|c|}
\hline $\begin{array}{c}\text { Показатели } \\
\text { для групn } \\
\text { респондентов }\end{array}$ & $\begin{array}{c}\text { Девушки } \\
15-18 \text { лет }\end{array}$ & $\begin{array}{c}\text { Женшины } \\
\text { 21-64 лет, } \\
\text { состояцие } \\
\text { в браке и вос- } \\
\text { питывающие } \\
\text { детей }\end{array}$ & $\begin{array}{c}\text { Юноши } \\
\text { 15-18 лет }\end{array}$ & $\begin{array}{c}\text { Мужчины } \\
\text { 20-55 лет, } \\
\text { состоячие } \\
\text { в браке и вос- } \\
\text { питываючиче } \\
\text { детей }\end{array}$ \\
\hline $\begin{array}{c}\text { Средние } \\
\text { значения }\end{array}$ & 5,54 & 5,71 & 5,43 & 5,57 \\
\hline $\begin{array}{c}\text { Стандартные } \\
\text { отклонения }\end{array}$ & 1,14 & 1,15 & 1,02 & 1,04 \\
\hline
\end{tabular}

Математический аппарат кластерного анализа с помощью методов автоматической классификации позволяет объединить объекты, сходные по различным признакам, в группы или кластеры. Эмпирические исследования установили, что понятия, объединяющиеся на расстоянии менее одного стандартного отклонения, воспринимаются испытуемыми как субъективно схожие, и их следует считать объектами одного семантического кластера.

Психосемантическая интерпретация основывается на принципе общего смысла, который семантически объединяет понятия кластера или фактора, и принципе маркировки с помощью понятий, которые служат семантическими маркерами, ориентирами для смыслового понимания близких к ним понятий. Психосемантическая модель диагностики предполагает, что близость понятий, обозначающих человеческие потребности, с понятиями, определяющими виды деятельности, измеряемыми с помощью шкал семантического дифференциала, свидетельствует, что данные потребности побуждают к рассматриваемым видам деятельности. На ее основе возможно выявить характеристики объекта и их динамику [16, 17].

\section{Результаты исследования}

Психосемантическую организацию понятий для групп респондентов позволяют выявить среднегрупповые дендрограммы, представленные на рисунках 1-4. На горизонтальной оси указано расстояние между понятиями в долях стандартного отклонения. В соответствии с пороговым расстоянием между 
RUSSIAN PSYCHOLOGICAL JOURNAL・2016 VOL. 13 \# 3

ними, равным 1,0 показателя среднеквадратичного отклонения, полученные дендрограммы разделены на кластеры понятий. Для них по принципу общего смысла, который определяется по одному из понятий семейной категории, входящим в данный кластер, предложены семантические темы (таблицы 2-8).

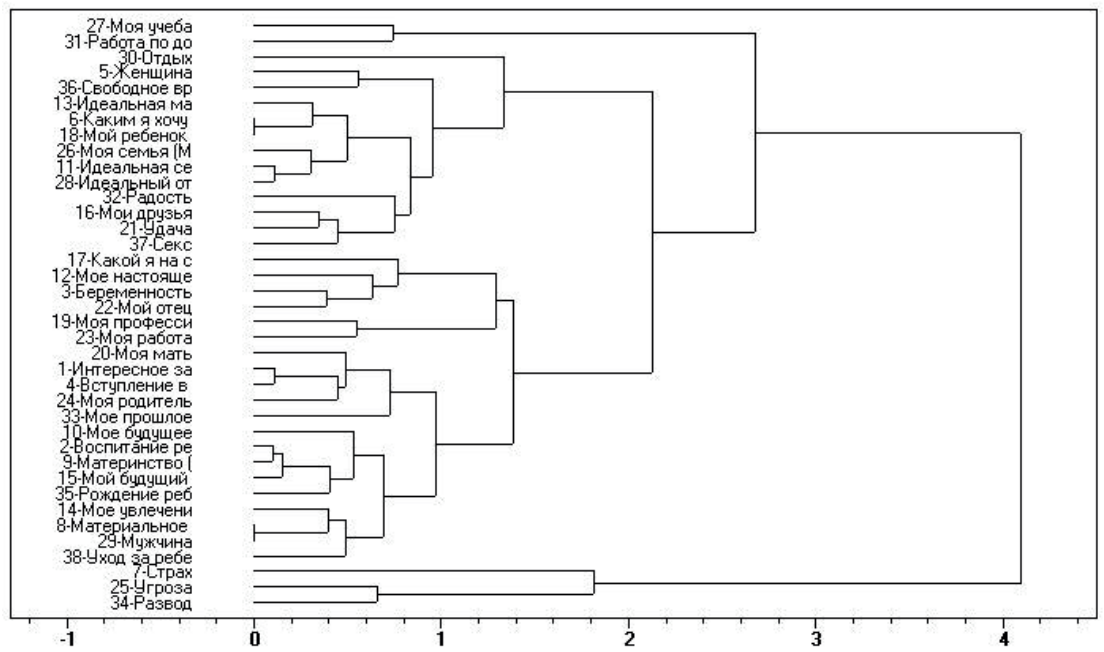

Рисунок 1. Дендрограмма понятий девушек 15-18 лет

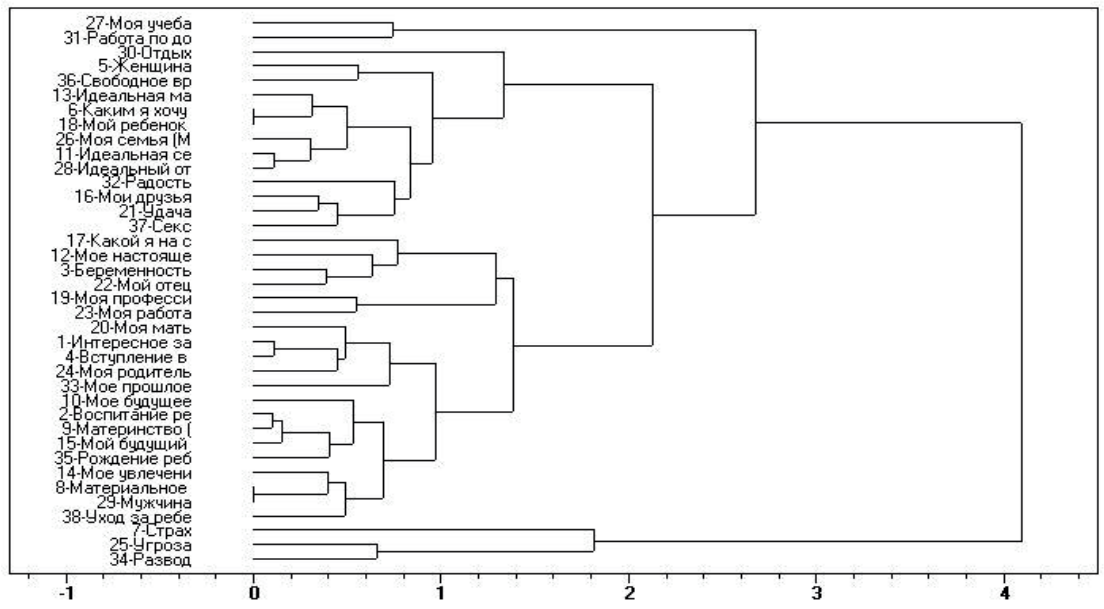

Рисунок 2. Дендрограмма понятий юношей 15-18 лет 


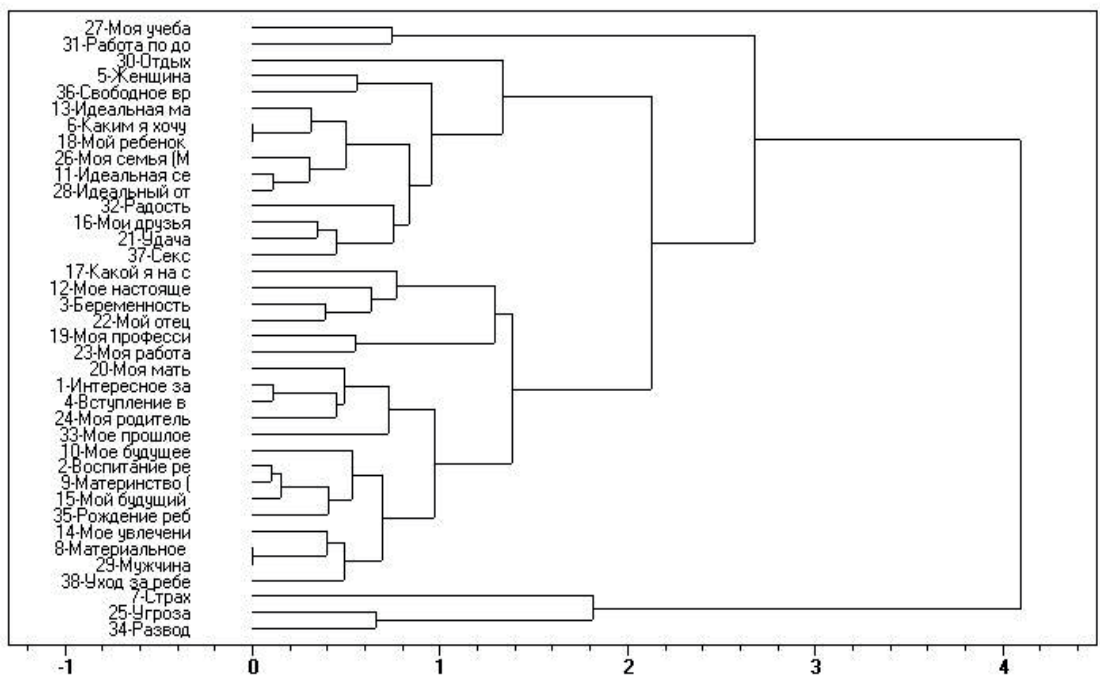

Рисунок 3. Дендрограмма понятий женщин 21-64 лет, состоящих в браке и воспитывающих детей

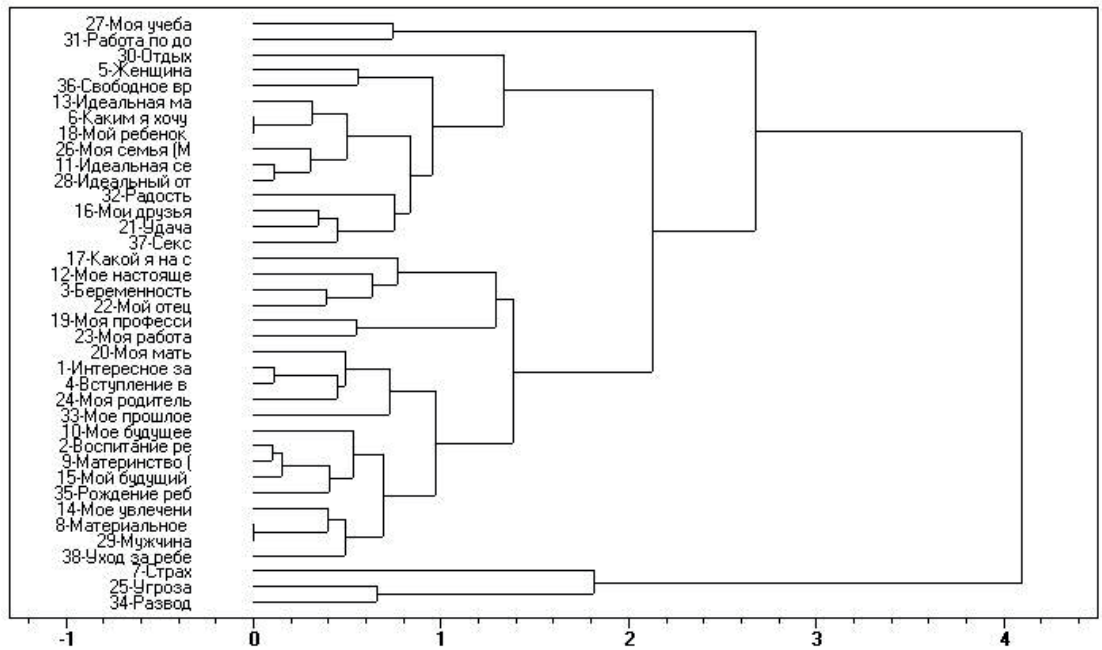

Рисунок 4. Дендрограмма понятий мужчин 20-55 лет, состоящих в браке и воспитывающих детей 
Модель структурного и функционального анализа психосемантической системы предложена нами на основе принципов общего смысла и маркировки психосемантической модели диагностики [17] и выводов теоретического анализа и эмпирических исследований, выполненных нами с целью решения первой эмпирической задачи $[5,6,7,8,9,10,11,12,13]$. Модель анализа включает следующие положения:

- семантический критерий позволяет выявить психосемантическую целостность и выполнить структурный и функциональный анализ объекта;

- структурная иерархическая организация психосемантической целостности в соответствии с общенаучной методологией системного анализа включает общесистемный, субсистемный и компонентный уровни;

- степень эмоциональной привлекательности объектов определяет фактор ценности объекта, который выделяет доминирующие системообразующие понятия;

- базовые потребности, характеризующие устойчивые интересы и увлечения. Содержание и интенсивность функциональных процессов, направленных на их удовлетворение, определяются динамичными связями с семантическими индикаторами времени, процесса идентификации, эмоциональной ценности и др.;

- виды деятельности и их необходимое количество, к которым побуждают жизненно важные потребности;

- психосемантические образования с высоким функциональным потенциалом, связанные с маркером мое будущее и определяющие планы и надежды респондента;

- ассоциации с настоящим временем, указывающие на содержание проблем в актуальной ситуации человека и краткосрочный функциональный процесс психосемантической структуры;

- психосемантическую связь с прошедшим временем, которая определяет генезис функционального ресурса системы и ее элементов;

- отсутствие ассоциаций потребностей с хронологическими категориями «прошлое», «настоящее» и «будущее», что предполагает фрустрацию в их удовлетворении, побуждает к поиску путей достижения цели и определяет степень функциональной активности;

- включение временных маркеров в разные кластеры, указывающих на динамичные функциональные процессы психосемантической системы, обусловленные сменой ценностных ориентаций и образа жизни;

- объединение потребностей и временных маркеров в одной семантически близкой группе понятий, что свидетельствует о стабильности, удовлетворении человека обстоятельствами в данной сфере жизни и отсутствии стремления к изменениям; 
- связь с понятием каким я хочу быть (какой я хочу быть) -семантическим маркером целенаправленности процесса социальной идентификации со значимыми людьми, группами или идеальными представлениями о них, определяет высокий функциональный потенциал семантической группы понятий;

- объединение в кластере понятия какой я на самом деле (какая я на самом деле) с другими людьми, группами или идеальными представлениями о них, что характеризует субъективное восприятие идентичности с ними и обуславливает определенный функциональный ресурс;

- маркеры позитивных или негативных эмоциональных переживаний и событий, которые свидетельствуют о субъективном отношении человека к рассматриваемой сфере жизни, людям или общностям и функциональной интенсивности определяющих его семантических структур;

- отсутствие ассоциаций с другими понятиями выявляет вытесненные комплексы, что может указывать или на безразличное отношение испытуемого к нему, или на сверхзначимое, но запретное и, вследствие этого, недоступное для осознания, или на болезненные переживания, связанные с ним, или оно ассоциируется с иными понятиями, не вошедшими в перечень данного исследования.

Анализ структуры психосемантической системы, выполненный для решения второй задачи исследования. Психосемантика семейной социально-психологической целенаправленности для всех групп респондентов имеет единый план структурно-уровневой организации на основе семейного семантического критерия:

- компонентный уровень, представленный базовыми понятиями-компонентами семейной сферы о членах семьи и семейных группах разных поколений, идеальных представлениях о них, событиях и видах деятельности, связанных с семейной жизнью, выбранными для исследования;

- субсистемный уровень содержит пять кластеров с общими для всех групп испытуемых семантическими темами: «Моя родительская семья», «Мой отец», «Моя будущая семья» / «Моя семья», «Мой муж» / «Моя жена» и «Рождение ребенка»;

- общесистемный уровень раскрывает структурные и качественные характеристики целостности и содержит кластеры, отражающие представления о двух поколениях семьи - родительском и современном (рисунки 1-4; таблицы 2-6).

Следовательно, психосемантические системы семейной социально-психологической целенаправленности различаются в зависимости от пола, возраста и семейного состояния групп респондентов по содержанию понятий и их ассоциативных связей в кластерах субсистемного уровня, что определяет 
необходимость дальнейшего изучения процессуальных функциональных особенностей психосемантических систем [13].

Функциональный анализ психосемантической системы семейной целенаправленности с применением теоретической модели анализа психосемантической системы. Для решения третьей эмпирической задачи на основе статичной структурной организации психосемантической системы выполним анализ динамичных качественных характеристик психосемантической системы семейной целенаправленности в зависимости от факторов возраста, пола и семейного состояния.

Доминирующие ченности в психосемантической системе. Дифференцированный анализ результатов показал, что для девушек максимальные оценки по фактору ценности имеют: понятие моя семья (моя будущая семья) -6,67, для юношей понятие моя жена (моя будущая жена) -6,50, а для женщин и мужчин понятие рождение ребенка-6,83 и 6,67 соответственно (таблицы 2-8) [5, 6].

Кластер «Моя родительская семья» (таблица 2). Представления о своей родительской семье для женщин в юности связаны с матерью и вступлением в брак, а в зрелости-с матерью, друзьями, материальным благополучием и сходством с родительской семьей. В отличие от мужчин, для женщин, как в юности, так и в зрелости, понятие моя родительская семья связано с базовыми интересами или увлечениями, что свидетельствует о его высокой функциональной значимости. Независимо от возраста для женщин родительская семья ассоциируется с прошедшим временем, что указывает на удовлетворение базовых потребностей в прошлом в родительской семье.

Таблица 2.

Кластер «Моя родительская семья»

\begin{tabular}{|c|c|c|c|}
\hline $\begin{array}{l}\text { Девушки } \\
\text { 15-18 лет }\end{array}$ & $\begin{array}{c}\text { Женцины 21- } \\
64 \text { лет, состоящие } \\
\text { в браке и воспиты- } \\
\text { вающцие детей }\end{array}$ & Юноши 15-18 лет & $\begin{array}{c}\text { Мужчины 20- } \\
55 \text { лет, состоя- } \\
\text { цие в браке и вос- } \\
\text { питываючие } \\
\text { детей }\end{array}$ \\
\hline \begin{tabular}{|l|} 
Моя мать $[5,83]$, \\
интересное заня- \\
тие $[6,00]$, вступле- \\
ние в брак $[6,17]$, \\
моя родительская \\
семья $[5,83]$, мое \\
прошлое $[5,50]$
\end{tabular} & $\begin{array}{l}\text { Мое увлечение } \\
{[6,00], \text { мои дру- }} \\
\text { зья [5,83], какая } \\
\text { я на самом деле } \\
{[5,83], \text { моя родитель- }} \\
\text { ская семья }[5,83], \\
\text { моя мать }[5,83], \text { ма- } \\
\text { териальное 6лаго- } \\
\text { получие }[5,67], \text { мое } \\
\text { прошлое }[5,17]\end{array}$ & $\begin{array}{l}\text { Беременность } \\
{[5,50], \text { мое насто- }} \\
\text { ящее }[5,00], \text { какой } \\
\text { я на самом деле } \\
{[5,50], \text { моя роди- }} \\
\text { тельская семья } \\
{[5,83], \text { мое про- }} \\
\text { шлое }[5,00], \text { уход } \\
\text { за ребенком [5,17] }\end{array}$ & $\begin{array}{l}\text { Моя родительская } \\
\text { семья [5,83], вос- } \\
\text { питание ребенка } \\
{[6,00], \text { материаль- }} \\
\text { ное благополучие } \\
{[6,00], \text { идеальный }} \\
\text { отец }[6,00], \text { уход } \\
\text { за ребенком }[6,00]\end{array}$ \\
\hline
\end{tabular}

Условные обозначения: жирный шрифт-эталонные понятия; в квадратных скобках-показатели по фактору ценности понятия для группы испытуемых. 
Мужчины в юности воспринимают свое сходство с родительской семьей. Объединяя по смыслу прошлое и настоящее время, в отличие от девушек этого возраста, они еще не готовы в настоящем к отделению от нее.

В зрелости мужчины связывают родительскую семью с идеалом отца, материальным благополучием и, возможно, ожидают помощи в уходе за ребенком и в его воспитании, а отсутствие в кластере семантических маркеров может свидетельствовать о снижении функциональной значимости кластера.

Кластер «Мой отец» (таблица 3) выделен в качестве функциональной единицы в психосемантических системах всех анализируемых групп, в отличие от понятия моя мать, которое не формирует самостоятельного кластера, а объединяется по ценностно-смысловому содержанию с разными кластерами семейной психосемантической системы.

Таблица 3.

Кластер «Мой отец»

\begin{tabular}{|c|c|c|c|}
\hline $\begin{array}{c}\text { Девушки } \\
\text { 15-18 лет }\end{array}$ & $\begin{array}{c}\text { Женцины 21- } \\
64 \text { лет, состоя- } \\
\text { щие в браке и вос- } \\
\text { питывающие } \\
\text { детей }\end{array}$ & Юноши 15-18 лет & $\begin{array}{c}\text { Мужчины 20- } \\
55 \text { лет, состоя- } \\
\text { щие в браке и вос- } \\
\text { питывающие } \\
\text { детей }\end{array}$ \\
\hline $\begin{array}{l}\text { Какая я на самом } \\
\text { деле }[5,50], \text { мое } \\
\text { настоящее }[4,83], \\
\text { беременность } \\
{[5,67], \text { мой отец }} \\
{[5,33]}\end{array}$ & $\begin{array}{l}\text { Мой отец }[5,00], \\
\text { работа по дому } \\
{[4,83]}\end{array}$ & $\begin{array}{l}\text { Мой отец [5,33], } \\
\text { мое будущее } \\
{[5,83], \text { идеальный }} \\
\text { отец }[5,83], \text { инте- } \\
\text { ресное занятие } \\
{[5,67], \text { каким }} \\
\text { я хочу быть }[6,00], \\
\text { мое увлечение } \\
{[5,83], \text { моя про- }} \\
\text { фессия }[5,50], \\
\text { материальное бла- } \\
\text { гополучие }[5,83], \\
\text { отцовство }[5,83], \\
\text { воспитание ребен- } \\
\text { ка }[5,67], \text { мужчина } \\
{[5,33]}\end{array}$ & $\begin{array}{l}\text { Каким я хочу } \\
\text { быть }[6,00], \text { отцов- } \\
\text { ство }[6,17], \text { какой } \\
\text { я на самом деле } \\
{[5,33], \text { мой отец }} \\
{[5,67]}\end{array}$ \\
\hline
\end{tabular}

Условные обозначения: жирный шрифт -эталонные понятия; в квадратных скобках-показатели по фактору ценности понятия для группы испытуемых.

Для женщин в юности отец семантически связан с беременностью, ощущением сходства с ним и с настоящим временем, а в зрелости только с работой по дому.

Наибольшее функциональное значение кластер «Мой отец» имеет для юношей и мужчин, определяя обретение мужской идентичности и содержания 
отцовства. В юношеском возрасте в кластере объединяются маркеры базовых интересов, увлечений, будущего времени с ощущением тождества с отцом, а также с представлениями о мужчине и идеальном отце, что побуждает к овладению профессией, достижению материального благополучия, отцовству и воспитанию ребенка. В зрелости отец ассоциируется с отцовством. Мужчины воспринимают сходство с ним и стремятся быть похожими на него. Семантическая близость маркеров каким я хочу быть и какой я на самом деле свидетельствует об ощущении достигнутой идентичности с отцом.

Кластер «Моя будущая семья» / «Моя семья» (таблица 4). Женщины, в отличие от мужчин, во все периоды жизни обладают семантически широко развернутым представлением о своей семье, связанным с различными маркерами функциональной активности.

Таблича 4.

Кластер «Моя будущая семья» / «Моя семья»

\begin{tabular}{|c|c|c|c|}
\hline $\begin{array}{l}\text { Девушки } \\
\text { 15-18 лет }\end{array}$ & $\begin{array}{c}\text { Женщины 21- } \\
64 \text { лет, состоя- } \\
\text { щие в браке и вос- } \\
\text { питывающие } \\
\text { детей }\end{array}$ & Юноши 15-18 лет & $\begin{array}{c}\text { Мужчины 20- } \\
55 \text { лет, состоя- } \\
\text { щие в браке и вос- } \\
\text { питывающие } \\
\text { детей }\end{array}$ \\
\hline $\begin{array}{l}\text { Женщина }[6,17], \\
\text { свободное время } \\
{[6,00], \text { идеальная }} \\
\text { мать }[6,50], \text { какой } \\
\text { я хочу быть }[6,33], \\
\text { мой будущий ре- } \\
\text { бенок }[6,33], \text { моя } \\
\text { будущая семья } \\
6,67], \text { идеальная } \\
\text { семья [6,33], иде- } \\
\text { альный отец [6,17], } \\
\text { радость }[6,50], \text { мои } \\
\text { друзья }[5,67], \text { удача } \\
{[6,33], \text { секс }[5,83]}\end{array}$ & $\begin{array}{l}\text { Женщина }[6,00], \\
\text { какой я хочу быть } \\
{[6,50], \text { мой ребенок }} \\
\text { (мой будущий ре- } \\
\text { бенок) [6,67], отдых } \\
{[6,67], \text { интересное }} \\
\text { занятие }[6,00], \text { мое } \\
\text { будущее }[6,00], \\
\text { моя семья }[6,00], \\
\text { вступление в брак } \\
{[6,17], \text { секс }[6,00],} \\
\text { идеальная мать } \\
{[6,67], \text { идеальная }} \\
\text { семья [6,50], иде- } \\
\text { альный отец [6,50], } \\
\text { воспитание ребен- } \\
\text { ка [6,17], материн- } \\
\text { ство [6,33], мое } \\
\text { настоящее }[5,83], \\
\text { беременность } \\
{[6,17], \text { уход за ре- }} \\
\text { бенком }[6,17]\end{array}$ & \begin{tabular}{|l} 
Идеальная семья \\
{$[6,17]$, моя будущая } \\
семья $[6,00]$, моя \\
мать $[6,00]$, иде- \\
альная мать $[6,17]$, \\
отдых [6,33], удача \\
{$[6,00]$, радость } \\
{$[6,17]$}
\end{tabular} & $\begin{array}{l}\text { Беременность } \\
{[6,17], \text { интересное }} \\
\text { занятие }[6,00], \text { иде- } \\
\text { альная семья [6,17], } \\
\text { идеальная мать } \\
{[6,00], \text { моя семья }} \\
{[6,33]}\end{array}$ \\
\hline
\end{tabular}

Условные обозначения: жирный шрифт -эталонные понятия; подчеркивание -понятия, доминирующие по фактору ченности; в квадратных скобках-показатели по фактору ченности понятия для группы испытуемых. 
В юности для женщин понятие о своей будущей семье имеет доминирующую ценность $(6,67)$ и ассоциируется с позитивными чувствами радости и удачи. Кластер содержит маркер процесса идентификации, который указывает, что девушки стремятся быть похожими на женщину, друзей, своего ребенка, идеалы матери, отца и семьи. В юности понятие о своей будущей семье предполагает свободное проведение времени и секс. Отсутствие в кластере временных маркеров свидетельствует о невозможности по причине возраста для девушек 15-18 лет получить желаемую ценность.

В зрелости у женщин развитие семантического содержания и функциональной интенсивности кластера «Моя семья» преобладает в психосемантике семейной социально-психологической целенаправленности. Удовлетворение базовых интересов, связанных со своей семьей, предполагает события вступления в брак и беременности, побуждает к различным видам деятельности-материнству, уходу за ребенком и его воспитанию, сексу и отдыху. Связь индикаторов базовых интересов, настоящего и будущего времени указывает на реализацию своих потребностей в настоящем и отсутствие планов изменить свою семейную жизнь в будущем. Процесс семейной идентификации женщин определяется семантикой своей семьи и целенаправлен на отождествление с женщиной, своим ребенком и своей семьей, с идеалами семьи, матери и отца.

Для мужчин в юности своя будущая семья ассоциируется с отдыхом, понятие о котором преобладает по фактору ценности в психосемантической системе $(6,33)$, а также с матерью, идеалами матери и семьи, с чувствами радости и удачи.

В зрелом возрасте своя семья связана с базовыми интересами мужчин и с представлениями о беременности и идеалах матери и семьи. Отсутствие в кластере временных маркеров указывает на неудовлетворение базовых интересов, что будет побуждать к решению проблемы в семейном поведении.

Кластер «Мой муж» / «Моя жена» (таблица 5). В юности функциональный потенциал кластера представлений о будущем супруге обусловлен связью с базовыми потребностями, планами на будущее (у девушек) и с доминирующими ценностями (у юношей).

Для женщин в юношеском возрасте понятие мой будущий муж связано с мужчиной, материальным благополучием, базовыми увлечениями и планами на будущее, побуждающими к рождению ребенка, деятельности материнства, уходу за ним и воспитанию. В зрелости понятие мой муж ассоциируется с учебой-деятельностью, которой женщины заняты на момент исследования.

Для мужчин в юности понятие моя будущая жена доминирует по фактору ценности среди других понятий $(6,50)$ и ассоциируется со свободным временем. В зрелости понятие моя жена вызывает чувство радости и побуждает 
к свободному проведению времени и отдыху. Мужчины относятся к ней так же, как к своей матери и ребенку.

Таблича 5.

Кластер «Мой муж» / «Моя жена»

\begin{tabular}{|c|c|c|c|}
\hline Девуики 15-18 лет & $\begin{array}{c}\text { Женцины } \\
\text { 21-64 лет, со- } \\
\text { стоячие в браке } \\
\text { и воспитываю- } \\
\text { щие детей }\end{array}$ & Юноши 15-18 лет & $\begin{array}{c}\text { Мужчины 20- } \\
55 \text { лет, состоя- } \\
\text { цие в браке и вос- } \\
\text { питывающие } \\
\text { детей }\end{array}$ \\
\hline \begin{tabular}{|l|} 
Мое будущее $[6,00]$, \\
воспитание ребенка \\
{$[5,83]$, материнство } \\
{$[6,00]$, мой будущий } \\
муж $[6,17]$, рожде- \\
ние ребенка $[6,17]$, \\
мое увлечение \\
{$[5,83]$, материальное } \\
благополучие $[5,67]$, \\
мужчина $[5,67]$, уход \\
за ребенком $[5,67]$
\end{tabular} & $\begin{array}{l}\text { Мой муж }[5,83], \\
\text { моя учеба }[5,83]\end{array}$ & $\begin{array}{l}\frac{\text { Моя будущая жена }}{[6,33], \text { свободное }} \\
\text { время }[5,83]\end{array}$ & $\begin{array}{l}\text { Моя жена }[6,17], \\
\text { мой ребенок (мой } \\
\text { будущий ребенок) } \\
{[6,17], \text { моя мать }} \\
{[6,00], \text { отдых }[6,50],} \\
\text { радость }[6,33]\end{array}$ \\
\hline
\end{tabular}

Условные обозначения: жирный шрифт - эталонные понятия; подчеркивание -понятия, доминирующие по фактору ченности; в квадратных скобках-показатели по фактору ченности понятия для группы испытуемых.

Кластер «Рождение ребенка» (таблица 6). В зрелом возрасте событие рождения ребенка, как для женщин, так и для мужчин, доминирует по эмоциональной привлекательности.

Таблича 6.

Кластер «Рождение ребенка»

\begin{tabular}{|c|c|c|c|}
\hline $\begin{array}{c}\text { Девушки } \\
\text { 15-18 лет }\end{array}$ & $\begin{array}{c}\text { Женцины 21- } \\
64 \text { лет, состоя- } \\
\text { щие в браке и вос- } \\
\text { питывающие } \\
\text { детей }\end{array}$ & Юноши 15-18 лет & $\begin{array}{c}\text { Мужчины 20- } \\
55 \text { лет, состоя- } \\
\text { щие в браке и вос- } \\
\text { питывающие } \\
\text { детей }\end{array}$ \\
\hline- & $\begin{array}{l}\text { Радость }[6,50], \\
\text { рождение ребенка } \\
{[6,83]}\end{array}$ & $\begin{array}{l}\text { Вступление в брак } \\
{[5,83], \text { мой будущий }} \\
\text { ребенок }[6,00], \\
\text { рождение ребенка } \\
{[6,17], \text { мои друзья }} \\
{[5,50], \text { секс }[5,83]}\end{array}$ & $\begin{array}{l}\text { Вступление в брак } \\
{[6,00], \text { удача }[6,00],} \\
\text { рождение ребенка } \\
{[6,67], \text { секс }[6,50]}\end{array}$ \\
\hline
\end{tabular}

Условные обозначения: жирный шрифт -эталонные понятия; подчеркивание-понятия, доминирующие по фактору ченности; в квадратных скобках-показатели по фактору ценности понятия для группы испытуемых. 
В дендрограмме женщин в юности понятие рождение ребенка не образует отдельного кластера, а объединяется с понятием о будущем муже в кластере «Мой будущий муж» (таблица 5) и ассоциируется с базовыми увлечениями, с будущим временем, с будущим мужем и мужчиной, материальным благополучием, и побуждает к деятельности материнства, уходу за ребенком и его воспитанию. В зрелости событие рождения ребенка $(6,83)$ доминирует по фактору ценности в дендрограмме и связано с чувством радости.

В дендрограмме мужчин в юности рождение будущего ребенка связано с представлением о нем, с дружескими отношениями, побуждает к вступлению в брак и сексу. В зрелости событие рождения ребенка, преобладающее по фактору ценности $(6,67)$, вступление в брак и секс ассоциируются с удачей-желательным результатом дела.

Кластеры понятий, которые не соответствуют семейному семантическому критерию, не входят в психосемантическую систему семейной социальнопсихологической целенаправленности (таблица 7).

В нашем исследовании установлено, что в юношеский период у девушек 15-22 лет представление о профессиональной и трудовой деятельности приобретает новый жизненно значимый смысл и становится основанием изменения структуры базисной мотивации личности, связанной с семьей и материнством [7, 11, 12].

Кластер «Моя работа». В настоящем исследовании установлено, что у женщин в возрасте 15-18 лет представления об учебе и работе по дому, о профессии и своей работе семантически не развиты. В зрелые годы они воспринимают как удачу желательную ситуацию, если профессия и работа связаны с мужчиной.

Для мужчин в юношеском возрасте выбор своей профессии ассоциируется с отцом, совокупностью базовых потребностей, планов на будущее, и включен в процесс идентификации, представленный в кластере «Мой отец», рассмотренном выше. Однако будущая профессия в их сознании ассоциируется не с учебной деятельностью, которой они занимаются в реальности, и не с работой, к которой их готовит обучение.

В зрелом возрасте у мужчин изменяется отношение к работе и учебе, его определяют базовые увлечения и дружеские отношения, которые реализуются во временном континууме «прошлое-настоящее-будущее», что указывает на высокую значимость и стабильность для них этой части жизни.

Кластер «Угроза». Для девушек развод представляет угрозу-возможную опасность, а для юношей и женщин угроза вызывает чувство страха (таблица 7).

Понятие развод обозначает расторжение супружеского брака, и в качестве события, относящегося к семейной жизни, оно было включено в список понятий для исследования. Однако в дендрограммах девушек, юношей, 
женщин и мужчин данное понятие разделено с ближайшим понятием семейной семантики расстоянием более четырех единиц стандартного отклонения (рисунки 1-4).

Таблица 7.

\section{Кластеры, не вошедшие в психосемантическую систему семейной} целенаправленности

\begin{tabular}{|c|c|c|c|c|}
\hline $\begin{array}{c}\text { Tема } \\
\text { кластера }\end{array}$ & $\begin{array}{l}\text { Девушки } \\
15-18 \text { лет }\end{array}$ & $\begin{array}{c}\text { Женщины } \\
21-64 \text { лет, } \\
\text { состоящие } \\
\text { в браке и вос- } \\
\text { питывающие } \\
\text { детей }\end{array}$ & $\begin{array}{l}\text { Юноши } \\
\text { 15-18 лет }\end{array}$ & $\begin{array}{c}\text { Мужчины } \\
20-55 \text { лет, } \\
\text { состоящие } \\
\text { в браке и вос- } \\
\text { питывающие } \\
\text { детей }\end{array}$ \\
\hline «Моя работа» & \begin{tabular}{|l|} 
Моя учеба \\
{$[4,33]$, рабо- } \\
та по дому \\
{$[4,17] .-$ Моя } \\
профессия \\
{$[5,67]$, моя ра- } \\
бота [5,67]
\end{tabular} & $\begin{array}{l}\text { Удача }[6,17], \\
\text { моя профес- } \\
\text { сия }[5,83], \text { моя } \\
\text { работа }[5,50], \\
\text { мужчина }[6,00]\end{array}$ & \begin{tabular}{|l} 
Моя учеба \\
{$[4,33] .-$ Моя } \\
работа $[5,50] .-$ \\
Работа по дому \\
{$[4,00]$}
\end{tabular} & $\begin{array}{l}\text { Мое насто- } \\
\text { ящее }[5,17], \\
\text { мои друзья } \\
{[5,50], \text { мое ув- }} \\
\text { лечение }[5,83], \\
\text { мое будущее } \\
{[6,00], \text { моя уче- }} \\
\text { ба }[5,33], \text { моя } \\
\text { работа }[4,83], \\
\text { мое прошлое } \\
{[4,83]}\end{array}$ \\
\hline «Угроза» & $\begin{array}{l}\text { Угроза }[2,00], \\
\text { развод }[2,00]\end{array}$ & $\begin{array}{l}\text { Страх }[2,17] \\
\text { угроза }[2,00]\end{array}$ & $\begin{array}{l}\text { Страх }[2,83], \\
\text { угроза }[2,17]\end{array}$ & - \\
\hline
\end{tabular}

Условные обозначения: жирный шрифт - эталонные понятия; в квадратных скобках-показатели по фактору ченности понятия для группы испытуемых. Тире - в дендрограммах девушек и юношей разделяет изолированные понятия.

Следовательно, семантическая качественная определенность понятия развод не соответствует семейному семантическому критерию и не входит в психосемантическую целостность семейной целенаправленности.

Изолированные понятия. В юности у женщин не вызывают ассоциаций понятия отдых и страх, а в зрелости-развод и свободное время. В юности у мужчин изолированы понятия женщина, развод, моя учеба, работа по дому и моя работа, а в зрелом возрасте-моя профессия, мужчина, работа по дому, женщина, свободное время, страх, угроза и развод. Таким образом, из понятий семейной темы не образует ассоциации понятие работа по дому только в группе юношей и мужчин (таблица 8). 


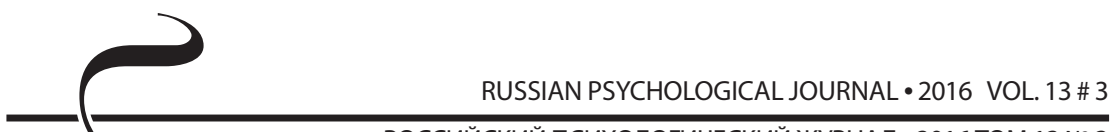

РОССИЙСКИЙ ПСИХОЛОГИЧЕСКИЙ ЖУРНАЛ • 2016 ТОМ 13 № 3

Таблица 8.

Изолированные понятия в дендрограммах

\begin{tabular}{|c|c|c|c|}
\hline $\begin{array}{l}\text { Девушки } \\
15-18 \text { лет }\end{array}$ & $\begin{array}{c}\text { Женшины } \\
\text { 21-64 лет, со- } \\
\text { стоящие в браке } \\
\text { и воспитываю- } \\
\text { щие детей }\end{array}$ & Юноши 15-18 лет & $\begin{array}{c}\text { Мужчины } \\
20-55 \text { лет, со- } \\
\text { стоящие в браке } \\
\text { и воспитываю- } \\
\text { чие детей }\end{array}$ \\
\hline $\begin{array}{l}\text { Отдых }[6,50] .- \\
\text { Страх }[2,33]\end{array}$ & $\begin{array}{l}\text { Развод }[2,00] .- \\
\text { Свободное время } \\
{[6,00]}\end{array}$ & $\begin{array}{l}\text { Женщина [6,17]. - } \\
\text { Развод }[2,17] .- \text { Моя } \\
\text { учеба }[4,33] .- \\
\text { Работа по дому } \\
{[4,00] . \text { - Моя работа }} \\
{[5,50]}\end{array}$ & $\begin{array}{l}\text { Моя профессия } \\
{[4,83] . \text { - Мужчина }} \\
{[5,67] . \text { - Работа }} \\
\text { по дому [4,83]. - } \\
\text { Женщина [6,00]. - } \\
\text { Свободное время } \\
{[5,83] . \text { - Страх }} \\
{[2,83] . \text { - Угроза }} \\
{[2,33] . \text { - Развод }} \\
{[2,00]}\end{array}$ \\
\hline
\end{tabular}

Условные обозначения: жирный шрифт -эталонные понятия; тире-разделяет изолированные понятия; в квадратных скобках-показатели по фактору ченности понятия для группы испытуемых.

Итак, сравнительный анализ на основе предложенной нами модели структурного и функционального анализа психосемантической системы позволяет выделить основные принципы системной структурно-функциональной модели организации психосемантической системы семейной челенаправленности для решения четвертой эмпирической задачи.

Общий принцип структурной и функциональной организации психосемантической системы семейной челенаправленности определяет семейный семантический критерий, который позволяет идентифицировать ее структурно-функциональные компоненты и их связи в психосемантической целостности.

Принцип структурной организации психосемантической целостности представлен:

во-первых, общесистемным уровнем психосемантической системы семейной целенаправленности, раскрывающим структурные и качественные характеристики целостности и содержащим представления о двух поколениях семьи-родительском и своем;

во-вторых, субсистемным уровнем, состоящим из пяти кластеров с общими семантическими темами, семантическая структура которых определяет системные функциональные задачи; 
в-третьих, компонентным уровнем, образованным базовыми компонентами-понятиями о членах семьи и семейных группах разных поколений, идеальных представлениях о них, событиях и видах деятельности, связанных с семейной жизнью.

Следовательно, психосемантические системы семейной целенаправленности различаются в зависимости от возраста, пола и семейного состояния по семантической структуре и содержанию субсистемных кластеров, что определяет необходимость дальнейшего функционального анализа указанных динамичных структур. Психосемантическая система семейной целенаправленности в сознании человека взаимодействует с психосемантическими целостностями иных сфер жизни и определяет семейное поведение.

Принцип системообразующей цели, целенаправленности функционального процесса психосемантической системы определяется доминирующими смыслообразующими ценностями психосемантического комплекса, динамика которых обусловлена факторами возраста, пола и семейного состояния.

Доминирование ценности понятия моя семья (моя будущая семья) для девушек сменяется ценностью рождение ребенка для женщин, состоящих в браке и воспитывающих детей, а предпочтение ценностей моя жена (моя будущая жена) и отдых для юношей сменяется ценностью рождение ребенка для мужчин, состоящих в браке и воспитывающих детей.

Принципы функциональной организации психосемантической целостности проявляются в целостной функциональности системной организации и хронологической динамике процесса реализации, в том числе:

- в изменениях ценностно-смыслового содержания структурной совокупности кластеров понятий, определяющих процессуальное качество ее функционального плана;

- в смене смыслообразующих доминирующих ценностей, определяющих функциональную целенаправленность психосемантической системы;

- в трансформации психосемантики базовых потребностей и возможности их удовлетворения посредством различных видов деятельности в прошлом, настоящем или будущем времени;

- в динамике временных категорий, выявляющих хронологическую специфику организации психосемантической целостности и ее структур;

- в переменах ценностно-смыслового содержания процесса семейной идентификации и восприятия своей семейной идентичности.

Таким образом, организация сравнительного исследования психосемантических систем под влиянием факторов пола, возраста и семейного состояния позволила выявить их основные структурно-функциональные качества на основе теоретической модели анализа объекта. 


\section{Выводы}

Модель структурного и функционального анализа психосемантической системы позволила выявить основные принципы организации модели семейной психосемантической челостности, в том числе:

1) общий принцип структурной и функциональной организации психосемантической целостности на основе семейного семантического критерия;

2) принцип структурной организации психосемантической целостности по единому плану системной иерархической организации;

3) принцип челенаправленности функционального процесса, обусловленный динамикой доминирующих ценностей рассматриваемой сферы жизни человека, выполняющих организующую смыслообразующую функцию в психосемантической целостности в зависимости от факторов пола, возраста и семейного состояния;

4) принцип функциональной организации психосемантической системы, который проявляется в целостной функциональной системности объекта и в хронологической динамике функционального процесса.

Результаты исследования могут быть использованы в теории и практике социально-психологической работы по формированию и коррекции семейно-ориентированного поведения.

\section{Литература}

1. Борзенков В. Г. Цель. Целенаправленность. Функция // Энциклопедия эпистемологии и философии науки. - М.: Канон + РООИ Реабилитация, 2009. - 1248 с.

2. Караваев Э. Ф. Моделирование. Модель // Энциклопедия эпистемологии и философии науки. - М.: Канон + РООИ Реабилитация, 2009. - 1248 с.

3. Карпов А. В. Психология сознания: метасистемный подход. - М.: Изд-во PAO, 2011. - 1088 c.

4. Ломов Б. Ф. Системность в психологии. -М.: Изд-во АПСН, 1996. - 384 с.

5. Нозикова Н. В. Динамика доминирующих понятий семейной и материнской направленности личности и ее значение в прикладной психологии // Психология XXI столетия / Под ред. В. В. Козлова. -Ярославль, 2006. - T. 3. - С. 34-38.

6. Нозикова Н. В. Доминирующие ценности семейной целенаправленности // Российский психологический журнал. - 2015. - Т. 12. - № 3. С. 89-104.

7. Нозикова Н. В. Материнская и семейно-ориентированная направленность девушек 15-22 лет: автореф. дисс. ... канд. психол. наук. -Ярославль: Изд-во Ярослав. гос. ун-та им. П. Г. Демидова, 2005. - 24 с.

8. Нозикова Н. В. Основные методологические подходы в исследовании 
социально-психологической направленности в сознании личности как системообразующего фактора социально-психологической общности // Вестн. Ярослав. гос. ун-та им. П. Г. Демидова. Сер. «Гуманит. науки». - 2011. - № 4. - С. 93-98.

9. Нозикова Н. В. Особенности представлений об отце у девушек 1517 лет // Российский психологический журнал. - 2014. - Т. 11. - № 1. C. 40-50.

10. Нозикова Н. В. Проблема изучения социально-психологической целенаправленности как системообразующего фактора интегральных качеств семьи // Вестн. Южно-Урал. ун-та. Сер. «Психология». - 2014. T. 7. - № 1. - С. 48-58.

11. Нозикова Н. В. Психосемантический подход в исследованиях семейной и материнской направленности девушек 15-17 лет // Культурно-историческая психология. - 2014. - Т. 10. - № 2. - С. 69-77.

12. Нозикова Н. В. Становление семейно-ориентированной и материнской направленности девушек-студенток // Психологическая наука и образование. - 2009. - № 1. - С. 90-97.

13. Нозикова Н. В. Структурный анализ психосемантической системы семейной социально-психологической целенаправленности // Культурноисторическая психология. - 2015. - Т. 11. - № 4. - С. 44-54.

14. Петренко В. Ф. Многомерное сознание: психосемантическая парадигма. - М.: Новый хронограф, 2010. - 440 с.

15. Серкин В. П. Психосемантика. - М.: Юрайт, 2016. - 318 с.

16. Соломин И. Л. Методика психосемантической диагностики мотивации (ПДМ). - СПб.: Речь, 2011. - 10 с.

17. Соломин И. Л. Психосемантический подход к исследованию трудовой мотивации: дисс. ... канд. психол. наук. -СПб.: Изд-во Рос. гос. пед. ун-та им. А. И. Герцена, 2009. - 179 с.

18. Osgood Ch. E. Lectures on Language Performance. - N. J. ect. cop., 1980. XI. $-276 \mathrm{p}$.

19. Osgood Ch. E. The nature and measurement of meaning // Psychol. Bull. 1952. -V. 49. - pp. 197-237.

20. Osgood Ch. E., Suci G. J., Tannenbaum P. H. The measurement of meaning. Urbana etc.: Univ. of Illinois Press, 1967. - 346 p.

\section{References}

1. Borzenkov V. G. Tsel'. Tselenapravlennost'. Funktsiia: Entsiklopediia epistemologii i filosofii nauki [Purpose. Purposefulness. Function: The encyclopedia of epistemology and the philosophy of science]. Moscow, Kanon + ROOI Reabilitatsiia Publ., 2009. 1248 p. 
2. Karavaev E. F. Modelirovanie. Model':Entsiklopediia epistemologii ifilosofii nauki [Modeling. Model: The encyclopedia of epistemology and the philosophy of science]. Moscow, Kanon + ROOI Reabilitatsiia Publ., 2009. 1248 p.

3. Karpov A. V. Psikhologiia soznaniia: metasistemnyi podkhod [The psychology of consciousness: a metasystem approach]. Moscow, Russian Academy of Sciences Publ., 2011. 1088 p.

4. Lomov B. F. Sistemnost' v psikhologii [Systemacy in psychology]. Moscow, Academy of pedagogical and social Sciences Publ., 1996. 384 p.

5. Nozikova N. V. Dinamika dominiruiushchikh poniatii semeinoi i materinskoi napravlennosti lichnosti i ee znachenie v prikladnoi psikhologii: Psikhologiia XXI stoletiia [The dynamics of dominant concepts of family and parent orientation of the person and its significance in applied psychology: Psychology of the XXI century]. Yaroslavl, 2006, V. 3, pp. 34-38.

6. Nozikova N. V. Dominiruiushchie tsennosti semeinoi tselenapravlennosti [Dominant values of family purposefulness]. Rossiiskii psikhologicheskii zhurnal - Russian Psychological Journal, 2015, V. 12, no. 3, pp. 89-104.

7. Nozikova N. V. Materinskaia i semeino-orientirovannaia napravlennost' devushek 15-22 let. Diss. kand. psikh. nauk [Parent and family-focused orientation of 15-22 years old girls. Cand. psych. sci. diss]. Yaroslavl, Yaroslavl State University Publ., 2005.

8. Nozikova N. V. Osnovnye metodologicheskie podkhody v issledovanii sotsial'no-psikhologicheskoi napravlennosti v soznanii lichnosti kak sistemoobrazuiushchego faktora sotsial'no-psikhologicheskoi obshchnosti [Basic methodological approaches in the study of socio-psychological orientation in the person's consciousness as a system-forming factor of a socio-psychological community]. Vestn. Iaroslav. gos. un-ta im. P. G. Demidova. Ser. "Gumanit. Nauki" - Bulletin of Yaroslavl State University, "Humanities" Series, 2011, no. 4, pp. 93-98.

9. Nozikova N.V. Osobennosti predstavlenii ob ottse u devushek 15-17 let [Features of representations of the father in 15-17 years old girls]. Rossiiskii psikhologicheskii zhurnal - Russian Psychological Journal, 2014, V. 11, no. 1, pp. 40-50.

10. Nozikova N. V. Problema izucheniia sotsial'no-psikhologicheskoi tselenapravlennosti kak sistemoobrazuiushchego faktora integral'nykh kachestv sem'i [The problem of studying socio-psychological orientation as a systemforming factor of integral qualities of the family]. Vestn. luzhno-Ural. un-ta. Ser. "Psikhologiia" - Bulletin of South-Ural. University, Series "Psychology", 2014, V. 7, no. 1, pp. 48-58.

11. Nozikova N. V. Psikhosemanticheskii podkhod $v$ issledovaniiakh semeinoi i materinskoi napravlennosti devushek 15-17 let [Psychosemantic approach to research family and parent orientation of 15-17 years old girls]. Kul'turno- 
istoricheskaia psikhologiia - Cultural-Historical Psychology, 2014, V. 10, no. 2, pp. 69-77.

12. Nozikova N. V. Stanovlenie semeino-orientirovannoi i materinskoi napravlennosti devushek-studentok [Formation of parental and familyfocused orientation in female students]. Psikhologicheskaia nauka i obrazovanie - Psychological Science and Education, 2009, no. 1, pp. 90-97.

13. Nozikova N. V. Strukturnyi analiz psikhosemanticheskoi sistemy semeinoi sotsial'no-psikhologicheskoi tselenapravlennosti [Structural analysis of the psycho-semantic system of a family socio-psychological purposefulness]. Kul'turno-istoricheskaia psikhologiia - Cultural-Historical Psychology, 2015, V. 11 , no. 4, pp. 44-54.

14. Petrenko V. F. Mnogomernoe soznanie: psikhosemanticheskaia paradigma [Multidimensional consciousness: the psychosemantic paradigm]. Moscow, Novyi khronograf Publ., 2010. 440 p.

15. Serkin V. P. Psikhosemantika [Psychosemantics]. Moscow, lurait Publ., 2016. $318 \mathrm{p}$.

16. Solomin I. L. Metodika psikhosemanticheskoi diagnostiki motivatsii (PDM) [The technique for psychosemantic diagnostics of motivation (PDM)]. St. Petersburg, Rech' Publ., 2011. 10 p.

17. Solomin I. L. Psikhosemanticheskii podkhod k issledovaniiu trudovoi motivatsii. Diss. kand. psikh. nauk [Psychosemantic approach to the study of motivation. Cand. psych. sci. diss]. St. Petersburg, Russian State Pedagogical University Publ., 2009. $179 \mathrm{p}$.

18. Osgood Ch. E. Lectures on Language Performance. N. J. ect. cop., 1980, XI. $276 \mathrm{p}$.

19. Osgood Ch. E. The nature and measurement of meaning. Psychol. Bull., 1952, V. 49, pp. 197-237.

20. Osgood Ch. E., Suci G. J., Tannenbaum P. H. The measurement of meaning. Urbana etc.: Univ. of Illinois Press, 1967. 346 p. 